\title{
The quality of life of patients with head neoplasms and incidence of depression treated with radiotherapy. A preliminary research report
}

\author{
Bogumiła A. Lubińska-Żądło' , Anna Pych², Bożena Kowalczyk', Bożena Zawadzka³ \\ 'Podhale State College of Applied Sciences in Nowy Targ, Nowy Targ, Poland \\ 2Jedrzej Sniadecki Specialist Hospital in Nowy Sacz, Nowy Sacz, Poland \\ ${ }^{3}$ Jan Kochanowski University in Kielce, Kielce, Poland
}

Introduction. The diagnosis of a primary tumor of the central nervous system is a source of huge fear and anxiety for a patient, because the prognosis is usually unfavorable. Very often, the cancer is accompanied by depression, which reduces the effectiveness of treatment and worsens the patient's functioning in everyday life.

The aim. The aim of the study is to determine the cause-and-effect relationship between quality of life and incidence of depression, as well as the side effects of treatment in people treated with radiation for head cancer.

Material and methods. The study group consisted of 103 patients during treatment in the Radiotherapy Ward of the Specialist Hospital in Nowy Sącz. The research tools were: the WHO QOL-Bref questionnaire, the Beck Depression Scale and a questionnaire of the author's own design regarding patients treated with radiation therapy for head cancer.

Results. The general perception of the quality of life in the studied group was 2.88 points, the general perception of the patient's own health was 1.88 points. The average quality of life was the highest in the environmental field: $62.50 \pm 23.21$, while the lowest in the physical field: $44.24 \pm 28.65$.

Conclusions. Both the overall assessment of the quality of life in the assessed areas and the perception of health by patients treated with radiation therapy for head cancer are low.

Key words: head cancer, depression, quality of life

\section{Introduction}

Radiation therapy is a very effective and one of the most commonly used methods of cancer treatment; at the same time it is one of the factors that cause increased stress in the oncological patient. This is associated with anxiety and the occurrence of side effects that can significantly affect the quality of life [1]. Treatment methods used in oncology are usually very aggressive, which causes anxiety in patients. As Walden-
-Gałuszko emphasizes, not knowing about the side effects and their consequences as well as the method of treatment is the most common reason for a patient's anxiety. The quality of life in patients treated with radiation therapy depends on multiple factors. The patient's ability to quickly adapt mentally to the situation has a significant impact. Moreover, the ability to deal with the side effects of early and late treatment is also of crucial importance during the treatment [2].

\section{How to cite:}

Lubińska-Żądło BA, Pych A, Kowalczyk B, Zawadzka B. The quality of life of patients with head neoplasms and incidence of depression treated with radiotherapy. A preliminary research report. NOWOTWORY J Oncol 2021; 71: 212-219. 
Radiotherapy is usually a kind of treatment that requires the patient to stay in an oncological center for several weeks, which can lead to anxiety for the patient. For a long time during the treatment, the patient can experience discomfort in life caused by various undesirable symptoms brought on by the radiation therapy [3]. Irradiation treatment is associated with a reduced intensity of side effects when compared to chemotherapy [4]. A diagnosis of cancer heightens the patient's fear, elevates anxiety, a sense of danger and the uncertainty of life. The image of this disease, which is common in society, evokes negative emotions [2]. On the one hand, the quality of life of a cancer patient is determined through the prism of the ailments or fears that accompany the disease, on the other hand, there is faith in treatment and a reduction of discomfort [5]. When diagnosing cancer, it seems necessary to start treatment as soon as possible.

For most patients, even staying in hospital is a big psychological problem and experience. A patient's value system is often radically changed. The onset of illness means that the person is at a level of basic needs, such as health, life and psychosomatic comfort. Safety and physical comfort are usually provided by the hospital, but the need for peace of mind is often not met. This is usually caused by a lack of communication between the patient and the medical staff. Providing information on the state of health, the course of the disease, the treatment and side effects, as well as establishing and maintaining vital emotional contact are all factors that are responsible for a patient's mental comfort. Another factor that reduces the quality of life of a hospitalized patient is the feeling of helplessness and passivity [2]. In scientific research, the basic and very often only criteria for assessing the effectiveness of oncological treatment was the survival time and remission period. Currently, more attention is paid to the impact of the disease and its treatment than on the patient's functional and psychological condition and their place in society [5].

The assessment of the quality of life of patients treated oncologically is of great interest in recent years. Cancer and depression are causes of a patient's suffering [6]. The concept of depression in the aspect of cancer is very important in many aspects. One of them is the occurrence of depression and mood disorders as a cause or factor of cancer [7, 8]. In such patients, there are disturbances and obstacles regarding cooperation in the treatment process [6]. Incidence of depression in patients with cancer is 3.5 times higher than in patients with diabetes, hypertension, heart disease, rheumatic arthritis, chronic lung disease or stroke [9].

The aim of the study was to determine the cause-and-effect relationship between the quality of life and the frequency and severity of depression and the side effects of radiation therapy in people treated for head cancer.

In order to achieve the aim of the work, the following research questions were asked:

1. How do patients treated with radiation for head cancer assess their quality of life?
2. What is the relationship between the assessment of the quality of life and the occurrence of depression in patients treated with radiation therapy for head cancer?

3. What is the relationship between the quality of life and the occurrence of side effects in the course of radiation therapy in patients treated for head cancer?

4. What is the relationship between the quality of life and the patient's attitude to the disease?

\section{Material and methods}

The research was conducted in the Radiotherapy Ward of the Specialist Hospital J. Śniadeckiego in Nowy Sącz. The diagnostic survey method was used. To assess the quality of life, the Polish version of the standardized WHO QOL-Bref questionnaire developed by Laura Wołowicka and Krystyna Jaracz, containing 26 questions, was used [10]. To assess the severity of depression, the Beck Depression Scale was used, consisting of 21 questions considering the most common symptoms of depression, whose translation and initial adaptation was undertaken by Parnowski and Jernajczyk [11]. The third tool was the author's own questionnaire focused on a group of patients treated with radiation for head cancers. The study group consisted of 103 adults, over 18 years of age, in whom radiotherapy was performed using an accelerator emitting photon radiation with the following energies: X6MV, X15MV, and electrons: E6MeV, E9MeV, E12MeV, E15MeV, E18MeV, E22MeV. The accelerator was equipped with multileaf colimators enabling conformal therapies in any location and IMRT (intensity modulated radiotherapy) therapies in the step and shot and sliding window technique [12]. In the case of multifocal metastases to the brain, the whole brain was irradiated. In primary lesions or single brain metastases, the area of the lesion was irradiated with a margin along with edema or the tumor bed. In the case of irradiation of the whole brain (palliative treatment), the hypothalamus was not protected. By contrast, in the case of irradiation of the primary tumor area (if possible), the minimum dose per hypothalamus was used.

Participation in the study was voluntary, the patients were informed about the purpose of the study, and they verbally agreed to take part in it.

The Chi independence test, the Mann-Whitney test and the Kruskel-Wallis test were used in the statistical analysis of the results. The choice of nonparametric tests was dictated by the lack of normality of variables (verified with the Kolmogorov-Smirnov and Shapiro-Wilk tests) or by the lack of group equivalence (verified with the $\mathrm{Chi}^{2}$ compliance test). A significance level of $p<0.05$ was adopted. The calculations were carried out using the IBM SPSS Statistics 20 program.

\section{Results}

One hundred three people aged 20-70 were examined (53.4\% men; $46.6 \%$ women). The largest group among all the respondents were patients between 41 and 50 years of age (34.0\%). Over half of the respondents (55.3\%) declared having 
secondary education. Few respondents (8.7\%) had higher education. Analyzing the marital status of the respondents, it was found that $68.9 \%$ of them were married. Single people accounted for only $18.4 \%$ of the respondents, and widowed patients constituted $12.6 \%$ of the respondents. Most frequently, respondents were diagnosed with glioblastoma multiforme (ICD-094) (34.0\%) or a metastatic tumor (ICD-094) (31.1\%) of the central nervous system. Less frequent was anaplastic astrocytoma (ICD-094) (14.6\%), anaplastic oligospermia (ICD-094) (10.7\%), germinal spinal cord (ICD-094) (6.8\%) or meningioma (ICD-095) (2.9\%).

Radiotherapy at a dose of $20 \mathrm{~Gy}$ in fractions of $4 \mathrm{~Gy}$ was used in $29.1 \%$ of patients and lasted 1 week. The most numerous group of $37.9 \%$ were patients treated for $2-3$ weeks with 30 Gy of irradiation in 3 Gy fractions; $24.3 \%$ of patients diagnosed with meningioma and/or patients who did not complete the treatment were treated for 4 to 5 weeks. Treatment with a dose of 60 Gy was used in $8.7 \%$ of the patients, in fractions of $2.0 \mathrm{~Gy}$, which lasted 6 weeks.

The most common effects of radiation were headaches (68.0\%). Slightly less often, the subjects suffered from nausea (44.7\%) or hair loss (42.7\%). Vomiting occurred in $25.2 \%$ of the respondents, and $16.5 \%$ of the respondents did not experience radiation side effects. Some patients experienced balance disorders (14.6\%) or blurred vision (5.8\%). Only a few of the respondents (13.6\%) used the help of a psychologist from the moment of diagnosis to the present. Most respondents (86.4\%) did not benefit from such assistance.

Analysis of the research showed that the respondents rated their quality of life higher (2.88) than their quality of health (1.88). In both cases, the self-assessment of the quality of life and health was very low (1-5 points scale) (tab. I).

The highest quality of life was observed in the environment field $(62.50 \pm 23.21)$, a lower one in the social field (50.16 \pm 31.35). The lowest indicator of the quality of life was observed

Table I. Individual overall perception of the quality of life and health

\begin{tabular}{|lcc|}
\hline & $\begin{array}{c}\text { Individual overall } \\
\text { perception of the } \\
\text { quality of life }\end{array}$ & $\begin{array}{c}\text { Individual overall } \\
\text { perception of the } \\
\text { quality of health }\end{array}$ \\
\hline mean & 2.88 & 1.88 \\
\hline median & 3.00 & 2.00 \\
\hline SD & 1.41 & 0.97 \\
\hline
\end{tabular}

in the psychological field $(46.93 \pm 31.73)$ and the physical field $(44.24 \pm 28.65)$ (tab. II).

On the basis of the Beck scale, it was found that $32.0 \%$ of people did not have symptoms of depression. Mild depression was observed in the group of $20.4 \%$ of respondents. Moderately severe depression was found in $34.0 \%$ of respondents, and very severe depression occurred in $13.6 \%$ of the respondents. It was shown that the lack of depression in $44.2 \%$ of the respondents or mild depression in $27.9 \%$ of the respondents was significantly more common in patients aged $20-40$ years. In $48.6 \%$ of people aged $41-50$ and $40.0 \%$ of people over 51 years of age, moderate depression was more frequent than in the rest of the respondents.

Analysis of the author's research shows that respondents without depression rated their overall quality of life the highest (4.30), slightly lower than the respondents with mild depression (3.67), the lowest quality of life rating was respondents with moderately severe (1.57) or very severe depression (1.64). The respondents rated their quality of health in a similar way. The respondents without depression rated their quality of life the highest (2.88), lower (1.81) - the respondents with mild depression, and those with moderately severe (1.34) or severe depression (1.00) rated their quality of health the lowest. Statistical analysis showed a relationship between depression and satisfaction with one's life and health $(p<0.0001)$. In this respect, people without depression showed a statistically significantly higher level of overall perception of quality of life and health than people with depression (tab. III).

It was shown that the lower the severity of depression, the higher the quality of life in individual subscales. The author's research shows that the quality of life in each of the assessed fields was significantly better in people without depression than in those with depression. As a result of the analysis, the differences found were statistically significant ( $p<0.0001$ ) (tab. IV).

Analysis of the research showed that respondents who had headaches as a side effect of radiation therapy rated their overall quality of life (3.10) and quality of health (2.10) higher than respondents who did not have headaches, who rated their overall quality of life (2.42) and quality of health (1.42) lower. Relationships were observed in each of the fields of the quality of life. People with headaches obtained average values of the quality of life in individual subscales at the level: in the physical field -47.50 , in the psychological field - 50.24, in the social field -55.24 , in the environmental field - 65.67;

Table II. The quality of life of patients treated for head cancer with radiation therapy

\begin{tabular}{|c|c|c|c|c|}
\hline & Physical field & Psychological field & Social field & Environment \\
\hline mean & 44.24 & 46.93 & 50.16 & 62.50 \\
\hline median & 39.29 & 41.67 & 41.67 & 59.38 \\
\hline SD & 28.65 & 31.73 & 31.35 & 23.21 \\
\hline $\min$. & 0 & 4 & 0 & 16 \\
\hline $\max$ & 89 & 96 & 100 & 94 \\
\hline
\end{tabular}


Table III. Individual perception of the quality of life and health

\begin{tabular}{|lccc|}
\hline $\begin{array}{l}\text { Depression (Beck } \\
\text { Depression Scale) }\end{array}$ & $\begin{array}{c}\text { Individual overall } \\
\text { perception of the } \\
\text { quality of life }\end{array}$ & $\begin{array}{c}\text { Individual overall } \\
\text { perception of the } \\
\text { quality of health }\end{array}$ \\
\hline $\begin{array}{l}\text { without } \\
\text { depression }\end{array}$ & mean & 4.30 & 2.88 \\
\hline $\begin{array}{l}\text { mild } \\
\text { depression }\end{array}$ & SD & 0.47 & 0.86 \\
\hline $\begin{array}{l}\text { moderately } \\
\text { severe } \\
\text { depression }\end{array}$ & mean & 3.67 & 1.81 \\
\hline $\begin{array}{l}\text { very severe } \\
\text { depression }\end{array}$ & mean & 0.86 & 0.40 \\
\hline in total & SD & 1.57 & 1.34 \\
\hline & mean & 0.70 & 0.68 \\
\hline$p$ & SD & 0.50 & 1.00 \\
\hline
\end{tabular}

and these values were higher than in people who did not have headaches. In the case of other side effects: vomiting, nausea, hair loss, and vision and balance disorders in patients treated with radiation for head tumors, similar relationships were observed as in the case of the headache. Both the respondents who did not have side effects of radiation therapy and those who did, assessed their overall quality of life and health in a similar way. A statistically significant dependence on all analyzed side effects of radiotherapy was found in the general perception of the quality of life and health, as well as in the social and environmental field. The obtained results concerning the most statistically significant relationships between variables at the significance level of $\mathrm{p}<0.0001$ revealed a relationship between hair loss and balance disorders and a subjective assessment of quality of life and health, and the quality of life for individual subscales (tab. V).

Table IV. The quality of life and depression in patients treated for head cancer

\begin{tabular}{|c|c|c|c|c|c|}
\hline Depression (Beck scale) & & Physical field & Psychological field & Social field & Environment \\
\hline \multirow[t]{2}{*}{ without depression } & mean & 78.03 & 84.97 & 87.37 & 88.45 \\
\hline & SD & 7.37 & 8.59 & 7.55 & 6.42 \\
\hline \multirow[t]{2}{*}{ mild depression } & mean & 52.21 & 54.56 & 58.73 & 69.35 \\
\hline & SD & 10.13 & 14.90 & 11.92 & 9.04 \\
\hline \multirow{2}{*}{$\begin{array}{l}\text { moderately severe } \\
\text { depression }\end{array}$} & mean & 21.22 & 21.79 & 23.81 & 43.21 \\
\hline & SD & 12.49 & 10.98 & 11.81 & 10.21 \\
\hline \multirow[t]{2}{*}{ very severe depression } & mean & 10.20 & 8.63 & 15.48 & 39.29 \\
\hline & SD & 8.03 & 3.45 & 13.81 & 19.02 \\
\hline \multirow[t]{2}{*}{ in total } & mean & 44.24 & 46.93 & 50.16 & 62.50 \\
\hline & SD & 28.65 & 31.73 & 31.35 & 23.21 \\
\hline$p$ & & $<0.0001$ & $<0.0001$ & $<0.0001$ & $<0.0001$ \\
\hline
\end{tabular}

Table V. The relationship between the quality of life and the side effects of radiation treatment

\begin{tabular}{|c|c|c|c|c|c|c|c|c|}
\hline $\begin{array}{l}\text { Side } \\
\text { effects }\end{array}$ & \multicolumn{2}{|c|}{ Occurence } & $\begin{array}{l}\text { Individual overall } \\
\text { perception of the } \\
\text { quality of life }\end{array}$ & $\begin{array}{l}\text { Individual overall } \\
\text { perception of the } \\
\text { quality of health }\end{array}$ & $\begin{array}{l}\text { Physical } \\
\text { field }\end{array}$ & $\begin{array}{l}\text { Psychological } \\
\text { field }\end{array}$ & $\begin{array}{l}\text { Social } \\
\text { field }\end{array}$ & Environment \\
\hline \multirow[t]{4}{*}{ headache } & \multirow[t]{2}{*}{ no } & mean & 2.42 & 1.42 & 37.34 & 39.90 & 39.39 & 55.78 \\
\hline & & SD & 1.56 & 0.50 & 28.19 & 29.57 & 30.64 & 26.68 \\
\hline & \multirow[t]{2}{*}{ yes } & mean & 3.10 & 2.10 & 47.50 & 50.24 & 55.24 & 65.67 \\
\hline & & SD & 1.29 & 1.07 & 28.48 & 32.38 & 30.60 & 20.85 \\
\hline$p$ & & & 0.0208 & 0.0027 & 0.0877 & 0.0714 & 0.0168 & 0.0422 \\
\hline \multirow[t]{4}{*}{ vomiting } & \multirow[t]{2}{*}{ no } & mean & 3.19 & 1.99 & 51.02 & 52.44 & 57.03 & 68.63 \\
\hline & & SD & 1.21 & 0.87 & 24.17 & 29.52 & 28.20 & 18.77 \\
\hline & \multirow[t]{2}{*}{ yes } & mean & 1.96 & 1.58 & 24.18 & 30.61 & 29.81 & 44.35 \\
\hline & & SD & 1.56 & 1.21 & 31.82 & 33.00 & 31.90 & 25.88 \\
\hline p & & & 0.0001 & 0.0022 & $<0.0001$ & 0.0039 & 0.0001 & $<0.0001$ \\
\hline \multirow[t]{4}{*}{ nausea } & \multirow[t]{2}{*}{ no } & mean & 3.33 & 2.05 & 56.39 & 58.85 & 62.43 & 71.44 \\
\hline & & SD & 1.31 & 0.89 & 25.43 & 30.40 & 29.26 & 20.96 \\
\hline & \multirow[t]{2}{*}{ yes } & mean & 2.33 & 1.67 & 29.19 & 32.16 & 34.96 & 51.43 \\
\hline & & SD & 1.33 & 1.03 & 25.23 & 27.01 & 27.14 & 21.17 \\
\hline$p$ & & & 0.0003 & 0.0070 & $<0.0001$ & 0.0001 & $<0.0001$ & 0.0001 \\
\hline
\end{tabular}




\begin{tabular}{|c|c|c|c|c|c|c|c|c|}
\hline $\begin{array}{l}\text { Side } \\
\text { effects }\end{array}$ & \multicolumn{2}{|c|}{ Occurence } & $\begin{array}{l}\text { Individual overall } \\
\text { perception of the } \\
\text { quality of life }\end{array}$ & $\begin{array}{l}\text { Individual overall } \\
\text { perception of the } \\
\text { quality of health }\end{array}$ & $\begin{array}{l}\text { Physical } \\
\text { field }\end{array}$ & $\begin{array}{c}\text { Psychological } \\
\text { field }\end{array}$ & $\begin{array}{l}\text { Social } \\
\text { field }\end{array}$ & Environment \\
\hline \multirow{4}{*}{$\begin{array}{l}\text { vision } \\
\text { disorders }\end{array}$} & \multirow[t]{2}{*}{ no } & mean & 3.00 & 1.94 & 45.66 & 48.28 & 51.72 & 63.66 \\
\hline & & SD & 1.37 & 0.98 & 28.94 & 32.22 & 31.66 & 23.43 \\
\hline & \multirow[t]{2}{*}{ yes } & mean & 1.00 & 1.00 & 21.43 & 25.00 & 25.00 & 43.75 \\
\hline & & SD & 0.00 & 0.00 & 0.00 & 0.00 & 0.00 & 0.00 \\
\hline$p$ & & & 0.0006 & 0.0088 & 0.0686 & 0.2520 & 0.0460 & 0.0157 \\
\hline \multirow{4}{*}{$\begin{array}{l}\text { balance } \\
\text { disorders }\end{array}$} & \multirow[t]{2}{*}{ no } & mean & 3.20 & 2.03 & 49.84 & 51.94 & 55.30 & 67.05 \\
\hline & & SD & 1.27 & 0.98 & 27.03 & 31.61 & 31.08 & 21.84 \\
\hline & \multirow[t]{2}{*}{ yes } & mean & 1.00 & 1.00 & 11.43 & 17.50 & 20.00 & 35.83 \\
\hline & & SD & 0.00 & 0.00 & 9.47 & 6.34 & 4.23 & 8.34 \\
\hline p & & & $<0.0001$ & $<0.0001$ & $<0.0001$ & 0.0006 & $<0.0001$ & $<0.0001$ \\
\hline \multirow[t]{4}{*}{ hair loss } & \multirow[t]{2}{*}{ no } & mean & 2.24 & 1.47 & 29.72 & 31.78 & 34.04 & 51.64 \\
\hline & & SD & 1.43 & 0.88 & 26.00 & 28.80 & 26.23 & 21.80 \\
\hline & \multirow[t]{2}{*}{ yes } & mean & 3.75 & 2.43 & 63.72 & 67.23 & 71.78 & 77.06 \\
\hline & & SD & 0.78 & 0.82 & 18.90 & 23.08 & 23.86 & 16.08 \\
\hline p & & & $<0.0001$ & $<0.0001$ & $<0.0001$ & $<0.0001$ & $<0.0001$ & $<0.0001$ \\
\hline \multirow{4}{*}{$\begin{array}{l}\text { no side } \\
\text { effects }\end{array}$} & \multirow[t]{2}{*}{ no } & mean & 2.88 & 1.95 & 44.73 & 47.72 & 51.55 & 62.86 \\
\hline & & SD & 1.38 & 1.03 & 29.80 & 32.28 & 32.20 & 23.93 \\
\hline & \multirow[t]{2}{*}{ yes } & mean & 2.88 & 1.53 & 41.81 & 42.89 & 43.14 & 60.66 \\
\hline & & SD & 1.58 & 0.51 & 22.51 & 29.38 & 26.39 & 19.74 \\
\hline$p$ & & & 1.0000 & 0.2064 & 0.5808 & 0.4589 & 0.3348 & 0.3585 \\
\hline
\end{tabular}

It was shown that respondents who accepted their illness perceived their quality of life the highest (4.33), which was higher than in respondents who somehow got used to it (2.85) or did not accept it (1.39). When analyzing the results of the research, the overall perception of the quality of health was similar. Those who had accepted their disease had a higher score (2.64) than those who had become used to the disease (1.85). The overall perception of the quality of health was rated the lowest by respondents who had not accepted their disease (1.13). The differences were statistically significant (tab. VI).

Table VI. Individual perception of the quality of life and the acceptance of the disease

\begin{tabular}{|c|c|c|c|}
\hline $\begin{array}{l}\text { The acceptance } \\
\text { of the disease }\end{array}$ & & $\begin{array}{l}\text { Individual } \\
\text { overall } \\
\text { perception } \\
\text { of the quality } \\
\text { of life }\end{array}$ & $\begin{array}{l}\text { Individual } \\
\text { overall } \\
\text { perception of } \\
\text { the quality of } \\
\text { health }\end{array}$ \\
\hline \multirow{2}{*}{$\begin{array}{l}\text { I accept the } \\
\text { disease. }\end{array}$} & mean & 4.33 & 2.64 \\
\hline & SD & 0.69 & 1.06 \\
\hline \multirow{2}{*}{$\begin{array}{l}\text { I do not accept the } \\
\text { disease. }\end{array}$} & mean & 1.39 & 1.13 \\
\hline & SD & 0.50 & 0.34 \\
\hline \multirow{2}{*}{$\begin{array}{l}\text { I feel accustomed } \\
\text { to the disease. }\end{array}$} & mean & 2.85 & 1.85 \\
\hline & SD & 1.04 & 0.74 \\
\hline \multirow[t]{2}{*}{ in total } & mean & 2.88 & 1.88 \\
\hline & SD & 1.41 & 0.97 \\
\hline$p$ & & $<0.0001$ & $<0.0001$ \\
\hline
\end{tabular}

It was found that the patients who had fully accepted their illness had the highest quality of life in each of the fields, the respondents who had got used to the disease had a lower quality of life, and the lowest were the patients who had not accepted their disease. A higher quality of life in particular fields was demonstrated by people accepting their illness: in the physical field: 72.75 , in the psychological field: 80.18 , in the social field: 79.55 , and in the environmental field: 84.28. The respondents who had not accepted their disease had the lowest quality of life in all fields: in the physical field: 17.51, in the psychological field: 15.86, in the social field: 20.97 , and in the environmental field: 40.83 . In terms of acceptance of the disease, the compared groups are the most diverse in the psychological field. While analyzing the obtained test results, there was a statistically significant relationship between the acceptance of the disease and the individual fields, which was $\mathrm{p}<0001$ (tab. VII).

\section{Discussion}

The Scientific Council of the National Cancer Registry states that in 2016 there was an increase in cancer incidence by about one thousand cases compared to 2015. This number also systematically increases in relation to cases of cancers of the central nervous system [13]. One of the methods of treating cancers of the central nervous system is the use of radiation therapy [14]. Very often, along with the occurrence of cancer, patients at various stages of the disease are accompanied by 
Table VII. The quality of life and the acceptance of the disease

\begin{tabular}{|c|c|c|c|c|c|}
\hline The acceptance of the disease & & Physical field & Psychological field & Social field & Environment \\
\hline \multirow[t]{2}{*}{ I accept the disease. } & mean & 72.51 & 80.18 & 79.55 & 84.28 \\
\hline & SD & 14.87 & 16.24 & 17.32 & 9.49 \\
\hline \multirow[t]{2}{*}{ I do not accept the disease. } & mean & 17.51 & 15.86 & 20.97 & 40.83 \\
\hline & SD & 10.65 & 8.96 & 15.35 & 13.33 \\
\hline \multirow[t]{2}{*}{ I feel accustomed to the disease. } & mean & 41.58 & 43.48 & 48.50 & 61.30 \\
\hline & SD & 25.35 & 25.65 & 27.43 & 20.82 \\
\hline \multirow[t]{2}{*}{ in total } & mean & 44.24 & 46.93 & 50.16 & 62.50 \\
\hline & SD & 28.65 & 31.73 & 31.35 & 23.21 \\
\hline p & & $<0.0001$ & $<0.0001$ & $<0.0001$ & $<0.0001$ \\
\hline
\end{tabular}

anxiety, anger and depression, which negatively affects the healing process and affects the quality of life [15].

Cancers of the central nervous system are not very common. However, the most common ones have a poor prognosis. According to the Scientific Council of the National Cancer Registry in Warsaw, cancer occurrence is estimated at 2\% per annum [16]. Dziadziuszko and Fijuth indicate that the incidence of glioblastoma multiforme is as much as $40 \%$, while metastatic tumors account for 15-20\% in patients with all cancers [15]. The research conducted in the radiotherapy ward confirms the fact that the most common cancers of the central nervous system are glioblastoma multiforme $34.0 \%$ and metastatic tumors to the central nervous system 31.1\%.

Kowalska and Szemik's research conducted among 225 people aged 25-44, using the WHO QOL-BREF questionnaire, showed that the average values of the quality of life for individual subscales were at these levels: for the physical field - 53.5, for the psychological field - 62.8, for social relations 70.0, and for the environmental field - 57.3 [17]. Kowalska et al. also assessed the quality of life of 746 healthy, professionally active people aged 45-60. The average of the individual fields was: somatic - 54.4, psychological - 60.8, social - 68.3 and environmental -57.6 [18]. Patients' quality of life deteriorates after the start of radiation and this condition persists for up to three months after the end of the treatment, as reported by Kozak et al. [19].

The analysis of the results of research showed that cancer and the treatment that is used significantly affect the quality of life of respondents in the physical, psychological and social field. The quality of life in the individual fields was as follows: the best results were obtained in the field of social relations - the average: 62.50; in the social field - the average: 50.16; in the environmental field - the average: 46.93 ; in the physical field - the average: 44.24 .

The occurrence of depression during cancer is a fairly common phenomenon. Studies by Mitchell et al. on the occurrence of depression during cancer show that the co- -occurrence of cancer and depression exceeds 50\% in many cases [20]. Onitilo et al. note in their publication that regardless of the etiology, the occurrence of depression in cancer patients has an additional impact on the results of the treatment. Patients with depression who are diagnosed with cancer experience a lower quality of life, their cooperation with medical staff is negatively affected and the patients are hospitalized longer [6]. The incidence of depression in patients treated with irradiation of the central nervous system is confirmed by the author's research. Based on the Beck Depression Scale, it was found that $32.0 \%$ of the respondents had no symptoms of depression. One in five patients $-20.4 \%$ - had mild depression. Moderately severe depression was found in $34.0 \%$ of the people, and $13.6 \%$ of the respondents had very severe depression. The results of research by Mitchell et al. conducted in a group of 279 oncological patients revealed the occurrence of major depression in $12.7 \%$, and depressive disorders in $29.6 \%$ of the subjects [21]. According to the authors, the diagnosis of depression in cancer patients should be more frequently analyzed, as depression in cancer patients can undoubtedly have a negative impact on the treatment process as well as on their cooperation with the medical staff.

Treating the central nervous system with irradiation is very often associated with the occurrence of various types of side effects. lonizing radiation affects both cancerous and healthy tissues. The author's research carried out in the radiotherapy ward indicates that the most common effects of radiation were headaches $-68.0 \%$. Slightly less frequently, the respondents had nausea $44.7 \%$ or hair loss $42.7 \%$. In the study of Kapela et al., $20.7 \%$ of respondents experienced pain during chemotherapy [22]. A cancer patient undergoing ionizing radiation treatment is a person who is suffering. Nowak et al. show that pain management results in better coping with its side effects, and in looking at the future - dealing with changes in the quality of life [23]. The author's research has shown that the side effects of radiation therapy: headache, vomiting, nausea, 
hair loss, vision and balance disorders significantly affect the overall perception of the quality of life and health.

Assessing the quality of life, especially its psychological sphere, it is crucial to adapt to the disease, i.e. the level of its acceptance, which is emphasized by Kurpas et al. [24]. In the studies by Smoleń et al., adapting to the disease in the studied group of cancer patients was at a medium level, however, people who did not experience pain and assessed their health well adapted better [25]. Szczepańska-Gieracha et al. indicate that among 71 patients with malignant neoplasms, strategies of coping with neoplastic disease may change with the time that elapses since the start of the treatment [26]. Research on the acceptance of cancer was carried out by Smolen et al. on a group of 229 randomly selected respondents. It was demonstrated that the higher the degree of cancer acceptance, the lower the severity of the helplessness-hopelessness relationship [27]. Ślusarska et al. assessed the level of acceptance of the disease and quality of life during treatment of patients with lymphoma using the WHO QOL-Bref questionnaire. Among 105 respondents, $7.6 \%$ of them showed a very low level of acceptance, and 15.2\% - a high level. The higher the level of acceptance, the better the quality of life of patients [28].

In the author's research, correlations were found between the level of the acceptance of the disease and the individual general perception of the quality of life and health in its individual areas.

Cancer puts people in a difficult position. Our physicality, mentality, community and human spirituality are all burdened. The reason for this can be any changes that occur in the patient's body, as well as various social factors. Very often, oncological diseases are accompanied by depression and anxiety, which significantly reduce the patient's quality of life and may affect the course of their treatment. Having the necessary knowledge about all stages of treatment and recovery, in both the physical and mental context, as well as the active participation in the process of treating of the patient and the family, can significantly affect the patient's self-esteem. The state of health of a patient treated with head irradiation for metastatic tumors often deteriorates rapidly, which is why J. Zapała et al. drew attention to the importance of health education; this is not only the transfer of knowledge and skills, but also instilling motivation to change one's behavior in order to have more effective treatment [29]. At present, there are few publications regarding the quality of life of patients undergoing radiation therapy for cancers of the central nervous system.

\section{Conclusions}

1. Respondents treated with radiation for head cancers rated their quality of life higher than their quality of health. In both cases, the self-assessment of the quality of life and health was very low.

2. Patients who did not have symptoms of depression rated their quality of life higher. Similarly, the higher the assessment of the quality of health, the lower the level of depression. It was shown that the higher the quality of life in specific fields, the lower the severity of depression in patients.

3. The intensity of side effects of radiation therapy for head tumors affects the assessment of the quality of life in specific fields. The greater the intensity of side effects of radiation therapy, the lower the quality of life in all fields. Patient education, carried out by a radiotherapy nurse that refers to how to deal with radiation reactions may significantly affect the patient's assessment of their quality of life.

4. The acceptance of the disease affects the perception of the quality of life. Patients who accepted their disease assessed their quality of life and health the highest, and those who did not accept the disease - rated it the lowest. It was shown that patients who fully accepted their disease had the highest quality of life in every field, a lower quality of life had those who got used to the disease, and the lowest the quality of life had patients who did not accept the disease.

\section{Conflict of interest: none declared}

\section{Bogumiła A. Lubińska-Żądło}

Podhale State College of Applied Sciences in Nowy Targ

ul. Kokoszków 71

34-400 Nowy Targ, Poland

e-mail:bogumila.lubinska@interia.pl

Received: 29 Dec 2020

Accepted: 20 Jan 2021

\section{References}

1. Kozakiewicz B. Nowotwory złośliwe narządu rodnego. Nowa Med. 2003: 122-127.

2. Walden-Gałuszko K. Psychoonkologia. 1st ed. Polskie Towarzystwo Psychiatryczne, Kraków 2000: 23-43.

3. Faller $\mathrm{H}$, Olshausen $\mathrm{B}$, Flentje $\mathrm{M}$. [Emotional distress and needs for psychosocial support among breast cancer patients at start of radiotherapy]. Psychother Psychosom Med Psychol. 2003; 53(5): 229-235, doi: 10.1055/s-2003-38864, indexed in Pubmed: 12709891.

4. Jacobsen PB, Andrykowski MA, Thors CL. Relationship of catastrophizing to fatigue among women receiving treatment for breast cancer. J Consult Clin Psychol. 2004; 72(2): 355-361, doi: 10.1037/0022006X.72.2.355, indexed in Pubmed: 15065968.

5. Jassem J. Paliatywna radioterapia, chemioterapia i leczenie hormonalne. In: Zapaśnik A, Żylicz Z. ed. Leczenie objawowe w chorobie nowotworowej - w okresie daleko zaawansowanym i terminalnym. Akademia Medyczna w Gdańsku, Gdańsk 1993.

6. Onitilo AA, Nietert PJ, Egede LE. Effect of depression on all-cause mortality in adults with cancer and differential effects by cancer site. Gen Hosp Psychiatry. 2006; 28(5): 396-402, doi: 10.1016/j.genhosppsych.2006.05.006, indexed in Pubmed: 16950374.

7. Jabłoński M, Furgał M, Dudek D, et al. [The position of psychooncology in contemporary psychiatry]. Psychiatr Pol. 2008; 42(5): 749-765, indexed in Pubmed: 19445357.

8. Pössel P, Adams E, Valentine J. Depression as a risk factor for breast cancer: investigating methodological limitations in the literature. Cancer Causes \& Control. 2012; 23(8): 1223-1229, doi: 10.1007/ s10552-012-0014-y.

9. Polsky D, Doshi JA, Marcus S, et al. Long-term risk for depressive symptoms after a medical diagnosis. Arch Intern Med. 2005; 165(11): 1260-1266, doi: 10.1001/archinte.165.11.1260, indexed in Pubmed: 15956005. 
10. Wołowicka L, Jaracz K. Wybrane problemy metodologii badań jakości życia związane ze stanem zdrowia. In: Wołowicka L. ed. Jakość życia w naukach medycznych. Wyd. Ucz. AM im. Karola Marcinkowskiego w Poznaniu, Poznań 2001: 233-258.

11. Zawadzki B, Popiel A, Pragłowska E. Psychometric Properties of the Polish Version of the Aaron T. Beck's Depression Inventory BDI-II). Psychologia-Etologia- Genetyka. 2009; 19: 71-95.

12. Oficjalna strona internetowa Szpitala Specjalistycznego im. J. Śniadeckiego w Nowym Sączu. http://www.szpitalnowysacz.pl/zaklad-radioterapii (06.05.2018)

13. Wojciechowska U, Didkowska J. Zachorowania i zgony na nowotwory złośliwe w Polsce. Krajowy Rejestr Nowotworów, Centrum Onkologii Instytut im. Marii Skłodowskiej-Curie. http://onkologia.org.pl/raporty (01.03.2019).

14. Tao Y, Daly-Schveitzer N, Lusinchi A, et al. Advances in radiotherapy of head and neck cancers. Curr Opin Oncol. 2010; 22(3): 194-199, doi: 10.1097/cco.0b013e3283388906, indexed in Pubmed: 20401975.

15. Szatkowska K, Dreger E, Basińska M. The sense of coherence and the attachment to God among oncological patients and their quality of life. Psychoonkologia. 2016; 20(1): 37-46, doi: 10.5114/pson.2016.60928.

16. Dziaduszko R, Fijuth J. Epidemiologia i etiologii. In: Dziaduszko R, Fijuth J. ed. Nowotwory ośrodkowego układu nerwowego. 2013: 36-37.

17. Kowalska M, Humeniuk M, Danso F, et al. [Quality of life of occupationally active people, aged $45-60$, living in the Polish industrial region (Silesian agglomeration)]. Med Pr. 2011; 62(5): 455-463, indexed in Pubmed: 22312959.

18. Kowalska M, Szemik S. Quality of life in adult inhabitants of Silesian voivodeship, aged 25-44 years - preliminary results. Probl Hig Epidemiol. 2016; 97(2): 172-176.

19. Kozaka J, Senkus-Konefka E, Kowalczyk A, et al. 310. Wpływ amifostyny na jakość życia chorych na nowotwory głowy i szyi otrzymujących radioterapię. Reports of Practical Oncology \& Radiotherapy. 2003; 8: S345-S346, doi: 10.1016/s1507-1367(03)70793-7.
20. Mitchell AJ, Lord K, Symonds P. Which symptoms are indicative of DSMIV depression in cancer settings? An analysis of the diagnostic significance of somatic and non-somatic symptoms. J Affect Disord. 2012; 138(1-2): 137-148, doi: 10.1016/j.jad.2011.11.009, indexed in Pubmed: 22310033.

21. Mitchell A, Chan $\mathrm{M}$, Bhatti $\mathrm{H}$, et al. Prevalence of depression, anxiety, and adjustment disorder in oncological, haematological, and palliative-care settings: a meta-analysis of 94 interview-based studies. The Lancet Oncology. 2011; 12(2): 160-174, doi: 10.1016/s1470-2045(11)70002-x.

22. Kapela I, Bąk E, Krzemińska S, et al. Evaluation of the level of acceptance of the disease and of satisfaction with life in patients with colorectal cancer treated with chemotherapy. Nursing and Public Health. 2017; 7(1): 53-61, doi: 10.17219/pzp/64689.

23. Nowak A, Babiarczyk B, Skoczylas K. The effect of pain control and management strategies on psychological adaptation to cancer. Journal of Public Health, Nursing and Medical Rescue. 2018; 3: 6-12.

24. Kurpas D, Bąk E, Seń M, et al. Quality of life in patients of the interventional cardiology unit. Family Medicine and Primary Care Review. 2014; 16(2): 120-123.

25. Smoleń E, Słysz M, Jarema M, et al. Czynniki warunkujące styl przystosowania do choroby u pacjentów leczonych onkologicznie. Journal of Education, Health and Sport. 2017; 7(08): 1715-1732.

26. Szczepańska-Gieracha J, Malicka I, Rymaszewska J, et al. Psychological adjustment of women after oncological surgery and at the end of treatment. Współczesna Onkologia. 2010; 6: 403-410, doi: 10.5114/ wo.2010.19166

27. Smoleń $\mathrm{E}$, Hombek K, Jarema M, et al. Factors determining the acceptance of the disease in patients treated oncologically. Medycyna Ogólna i Nauki o Zdrowiu. 2018; 24(1): 37-43, doi: 10.26444/monz/86142.

28. Ślusarska B, Nowicki GJ, Serwata M. Level of disease acceptance and quality of life in people with lymphoma. Palliative Medicine. 2016; 8(2): 88-95.

29. Zapała J, Zawadzka B, Pyk M. Cancer and diabetes - similarities and differences in prevention. Probl Hig Epidemiol. 2018; 99(3): 205-210. 